\title{
Assessing the distinctiveness of the Cultus pygmy sculpin, a threatened endemic, from the widespread coastrange sculpin Cottus aleuticus
}

\author{
Patricia E. Woodruff, Eric B. Taylor ${ }^{*}$ \\ Department of Zoology and Biodiversity Research Centre and Beaty Biodiversity Museum, University of British Columbia, \\ Vancouver, British Columbia V6T 1Z4, Canada
}

\begin{abstract}
The Cultus pygmy sculpin is a cottoid fish endemic to Cultus Lake, southwestern British Columbia, Canada, and is listed as 'threatened' under the federal Species at Risk Act (SARA). The Cultus pygmy sculpin was first discovered and described as a 'dwarf' coastrange sculpin Cottus aleuticus in the 1930s. It matures at a smaller size than the 'normal' C. aleuticus, has a lacustrine life history rather than a fluvial one, has different morphological features, and appears to undertake diurnal feeding migrations into the water column to feed on Daphnia, but little else of its biology is known. We used molecular genetic and behavioural assays to further assess the level of differentiation between Cultus pygmy sculpin and stream-dwelling C. aleuticus from several locations. Mitochondrial DNA haplotypes were broadly shared between Cultus pygmy sculpin and coastrange sculpin, and there was no apparent phylogeographic structure. However, analysis of 8 microsatellite analysis loci indicated significant genetic differentiation between parapatric samples of both forms. Laboratory-based experiments showed that, in general, the Cultus pygmy sculpin was found higher in the water column and was more active off the bottom than coastrange sculpin, but these behavioural differences were influenced by the presence of congeneric C. asper. Molecular and behavioural results support the recognition of the Cultus pygmy sculpin as a conservation unit distinct from 'typical' C. aleuticus because there is some level of genetic and behavioural discreteness between the forms, and behavioural differences may represent an important aspect of the pelagic life style of the Cultus pygmy sculpin.
\end{abstract}

KEYWORDS: Fish - Threatened species - Designatable units - Behaviour - Microsatellites · Mitochondrial DNA

Resale or republication not permitted without written consent of the publisher

\section{INTRODUCTION}

The significance of intraspecific groupings of taxa for conservation management is increasingly being recognized; such groupings signal the often rich bioheritage of individual taxa (e.g. Bowen 1999), and can represent variation important to promoting species persistence over temporally and spatially variable environments (e.g. Hilborn et al. 2003). While the concept of recognizing intraspecific variation in conservation plans is well accepted, how to recog- nize and prioritize alternative groups proposed for conservation has proven to be more challenging. In the USA, under the Endangered Species Act (ESA), and in Canada, under the Species at Risk Act (SARA), objective criteria have been proposed, dealing with 'discreteness' (e.g. assessed by genetics, behaviour or geography) of intraspecific populations and 'evolutionary significance' (e.g. in terms of evolutionary legacy or local adaptation) of that discreteness, to recognize distinct population segments and designatable units (DUs), respectively, as legally 
listable 'species'. In some cases, however, what are thought to be evolutionarily distinct units were recognized and listed before these criteria had been developed or assessed objectively.

The geoclimatic history of British Columbia (BC), Canada, involved repeated glacial advances and retreats during the Pleistocene $(\sim$ the last 2 million years), and BC has only about 70 taxonomically recognized freshwater fish species (McPhail 2007). During Pleistocene glacial advances, the BC freshwater fish fauna was either eliminated or restricted to icefree refugia peripheral to the main ice sheets, and the contemporary freshwater fish fauna consists almost entirely of postglacial immigrants (McPhail 2007). The BC freshwater fish fauna, therefore, is characterized by relatively low taxonomic diversity, but contains many examples of highly divergent 'ecotypes', intraspecific phylogenetic groups and biological species that have yet to be described formally (e.g. McPhail 1984, 2007, Taylor 1999).

An example of such an ecotype is the Cultus pygmy sculpin, thought to be a derivative of the coastrange sculpin Cottus aleuticus, which was first identified by Ricker (1960) and is endemic to Cultus Lake in southwestern BC. The Cultus pygmy sculpin is different from 'typical' coastrange sculpin in that it resides and matures at a smaller size in the lake's pelagic environment (Ricker 1960, McPhail 2007). A close relative of the coastrange sculpin, the prickly sculpin C. asper is also found in Cultus Lake, but there apparently only in littoral and benthic habitats (McPhail 2007). Cultus pygmy sculpin are thought to occupy only the deeper, offshore waters of the lake, based on the lack of observations of the ecotype during shore and tributary sampling (Ricker 1960). Since 1970, Fisheries and Oceans Canada (DFO) have captured Cultus pygmy sculpins during sampling for sockeye salmon Oncorhynchus nerka using pelagic trawls in Cultus Lake (J. Hume pers. comm.). It is thought that the Cultus pygmy sculpin undertakes diurnal feeding migrations, following the zooplankton on which it feeds (McPhail 2007). Limnetic life histories, however, are extremely rare in the Cottidae. In fact, only 3 species of the 250 or so described taxa are wholly limnetic as adults, and these belong to 2 highly divergent genera endemic to Lake Baikal in central Siberia (Kontula et al. 2003).

The Cultus Lake pygmy sculpin is a provincially red-listed species (meaning that it is an indigenous species listed as 'threatened' in BC) as its range is restricted to a single lake that is used intensively: Cultus Lake received 3 million recreational visitors in 2009 (Cultus Lake Park Board minutes, September
2009; BCCDC 2012). The Cultus pygmy sculpin is a recognized DU and is legally listed under SARA on Schedule 1 as a 'threatened' species, which means that recovery planning and critical habitat protection are mandatory, and a recovery strategy for this DU has been completed (National Recovery Team for Cultus Pygmy Sculpin 2007). The 'threatened' status of the Cultus pygmy sculpin is based on its apparent rarity, some evidence of declines in abundance, and threats to its habitats (COSEWIC 2010). Despite the status of the Cultus pygmy sculpin, the only studies on this fish to date were conducted by Ricker in 1932 to 1937 (Ricker 1960) and the status reports of the Committee on the Status of Endangered Wildlife in Canada (COSEWIC), an independent body whose primary mandate is to assess the conservation status of Canadian wildlife species (e.g. COSEWIC 2010). COSEWIC (2010) reported some differences in life history and morphology between Cultus pygmy sculpin and typical coastrange sculpin. For instance, Cultus pygmy sculpin have a pelagic life-style and small size at maturity, and also exhibit enlarged cephalic pore, smaller pelvic fins, and more pectoral fin rays than the typically stream-dwelling coastrange sculpin (COSEWIC 2010, E. B. Taylor unpubl. data). Cephalic pores are located on the underside of the head and are important in sensory perception in fishes. The small size, large cephalic pores and paired fin characteristics of Cultus pygmy sculpin have been interpreted as potential adaptations to a pelagic life style (McPhail 2007, COSEWIC 2010). Notwithstanding these differences, which may in part reflect phenotypic plasticity, there have been no genetic assessments of the status of the Cultus pygmy sculpin as a valid DU under the discrete and significance criteria of COSEWIC. For instance, it is possible that the 2 forms are part of the same genetic population and that the lake form results from dispersal from the stream-spawning habitats of coastrange sculpin. Alternatively, the lake form may be a genetically discrete population that, coupled with its ecological specializations, is behaving as a species distinct from coastrange sculpin. This is an important unknown because although the Cultus pygmy sculpin is currently listed by SARA, the status of COSEWIC DUs and their legal listings are reassessed at least every 10 yr. Consequently, the conservation status of any DU may change and the eligibility of a wildlife species as a DU is one basis on which the status may be altered. Further, there have been no detailed studies on this fish since Ricker's (1960) original work, and little of its life history is known. A phenotypically similar pelagic form of Cot- 
tus aleuticus, however, has been found in Lake Washington near Seattle, Washington (USA), about $160 \mathrm{~km}$ southwest of Cultus Lake (Larson \& Brown 1975). The evolutionary origin of these similar ecotypes, however, is uncertain. This other pelagic sculpin could share a common ancestor with the Cultus pygmy sculpin or it could have arisen through parallel evolution.

In this study, we examined mitochondrial (mtDNA) and microsatellite DNA variation in Cultus pygmy sculpin and compared them to populations of coastrange sculpin within and outside the Cultus Lake drainage to directly assess their level of genetic distinctiveness. We also conducted a behavioural study to test for differences in depth selection between Cultus pygmy sculpin and stream-dwelling Cottus aleuticus. Because Cultus pygmy sculpin have a pelagic lifestyle and feed heavily on zooplankton in mid-water (Ricker 1960), as opposed to the benthic, lithophilic lifestyle of stream-dwelling coastrange sculpin, we predicted that Cultus pygmy sculpin would exhibit a preference for higher positions in the water column. A similar rationale and tests were used to assess differences in depth preference between limnetic forms of lake whitefish Coregonus clupeaformis compared to sympatric, but more bottom-oriented benthic forms (Rogers \& Bernatchez 2007).

\section{MATERIALS AND METHODS}

\section{Study area and samples}

Cultus Lake is located approximately $10 \mathrm{~km}$ south of Chilliwack, in the eastern portion of the lower Fraser River Valley of southwestern BC (Shortreed 2007; Fig. 1). The surface area of the lake is $6.3 \mathrm{~km}^{2}$, and it has a mean depth of $31 \mathrm{~m}$, with a maximum depth of $44 \mathrm{~m}$ (Shortreed 2007). Frosst Creek is the lake's inlet stream and largest tributary; the lake discharges into Sweltzer Creek, which itself empties into the Chilliwack River (a tributary of the lower Fraser River) approximately $3 \mathrm{~km}$ downstream from the lake (Shortreed 2007). Cultus Lake is warm, monomictic and thermally stratified from May to November (Shortreed 2007). The lake is mesotrophic, and there has been an increase in lake temperature over the past $70 \mathrm{yr}$ which has been accompanied by an increase in productivity (Shortreed 2007).

A total of 46 different samples from 13 different locations were used to obtain mtDNA sequences, including 3 from Cottus asper (Table 1). A homologous sequence from the European bullhead $C$. gobio was obtained from GenBank (accession no. AY453756.1). This sequence and sequences from $C$. asper were used as outgroup taxa in the mtDNA analyses. The mtDNA data were used to confirm the identity of Cultus pygmy sculpin as a derivative of coastrange sculpin by DNA barcoding and to assess any deeper phylogeographic differences between the 2 populations relative to representative collec-

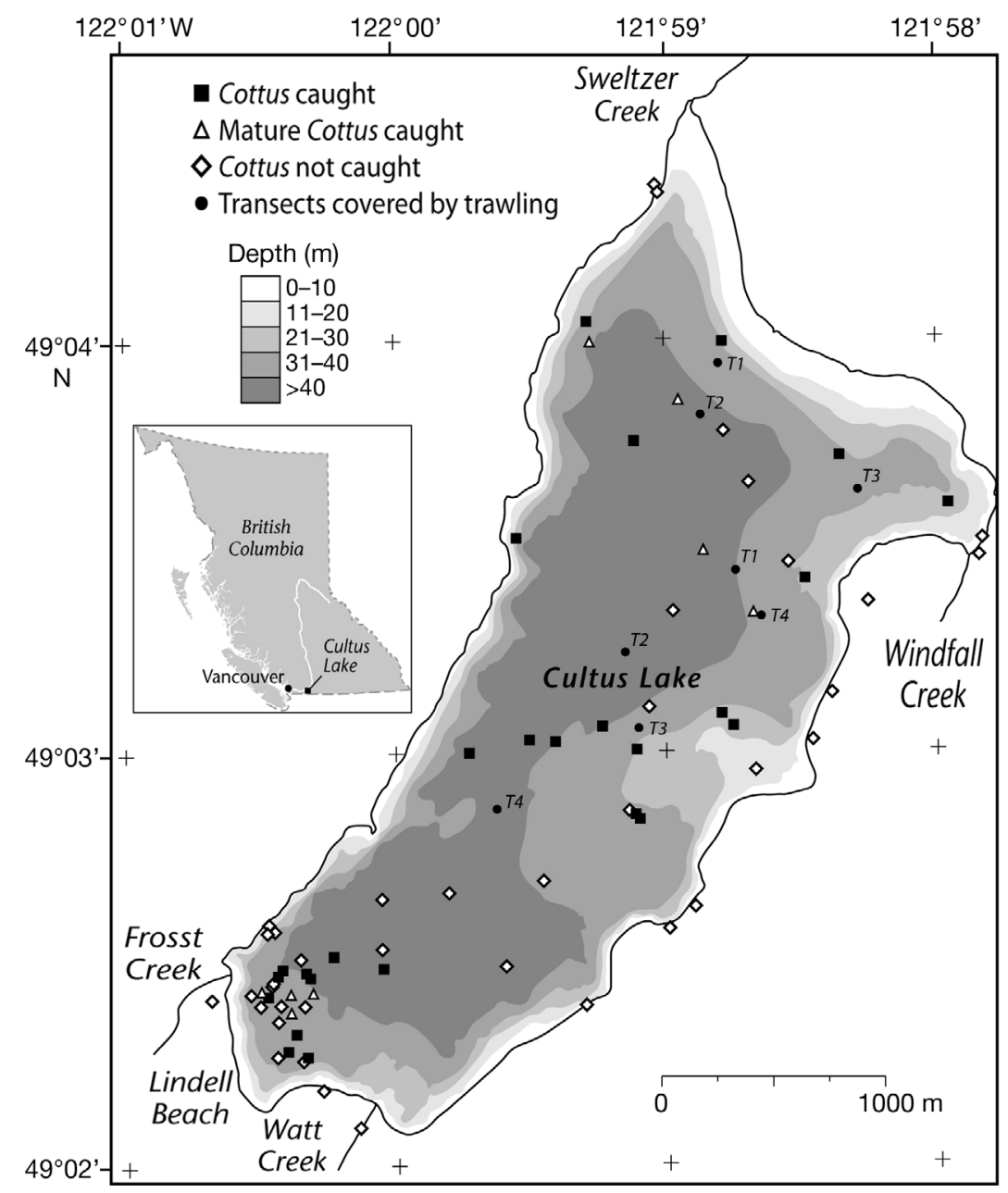

Fig. 1. Cultus Lake bathymetry (10 m intervals), modified from Shortreed (2007). Inset shows location of Cultus Lake in British Columbia, Canada. Mature Cottus were identified by the presence of eggs or testes. The 4 trawl transects are denoted by straight line distances between points T1 through T4 (i.e. Trawls 1-4) 
tions from outside Cultus Lake, including one from Lake Washington (in nearby Washington State, USA) which has also been described as a pygmy, pelagic form of C. aleuticus (e.g. Larson \& Brown 1975), but whose affinities with the Cultus pygmy sculpin are unknown. We also obtained 350 samples from 9 different locations to test for finerscale genetic differentiation between Cultus pygmy sculpin and coastrange sculpin, particularly within the Cultus Lake watershed, using microsatellite DNA analysis (Table 1). Samples were captured by trawl (T1-T4; Fig. 1), minnow trap or electrofishing (Smith-Root Model 12-B). The shoreline of Cultus Lake was sampled using minnow traps deployed from shore, while the pelagic area was sampled using minnow traps suspended off the bottom of the lake by a float, $10 \mathrm{~m}$ apart, and at depths that ranged from 10 to $40 \mathrm{~m}$. The minnow traps were baited with canned salmon and Cyalume yellow $12 \mathrm{~h}$ 'glow sticks' which have been shown to help attract deepwater sculpin Myoxocephalus thompsonii (Sheldon et al. 2008).

To sample fish for the behavioural assays, the minnow traps in Cultus Lake were deployed in the same area as that swept by the trawl net during the DFO juvenile sockeye salmon surveys (Fig. 1), and the fish were captured in May, September and October. The Little Campbell River was chosen as a population outside Cultus Lake that represents the typical stream-dwelling form of Cottus aleuticus. The Little Campbell River flows into Semiahmoo Bay, just south of the Fraser River estuary, and it is unlikely there is any gene flow between sculpins from Little Campbell River and the Cultus Lake drainage. Live fish were brought back to an environmental chamber in the Biological Sciences building at the University of British Columbia (UBC), and were kept in 1361 aquaria with approximately 10 to 15 fish $\operatorname{tank}^{-1}$. Fish from Cultus Lake, Frosst Creek and the Little Campbell River were maintained in separate aquaria at 14 to $16^{\circ} \mathrm{C}$ for about 1 mo before the behavioural experiments began.

\section{Mitochondrial DNA}

Tissue samples were subject to Qiagen spin column-based DNA extraction procedures and the DNA was stored at $-20^{\circ} \mathrm{C}$. The entire control region was amplified by PCR using the primers L-Thr (5'AGC TCA GCG YCA GAG CGC CGG TCT TGT AA-3') and H12Sr5 (5'-TGA TAA TAA AGT CAG GAC CAA G-3') (Yokoyama \& Goto 2002). Amplification reactions contained 50 to $300 \mathrm{ng}$ of genomic DNA template. The control region of mtDNA was amplified in a $50 \mu \mathrm{l}$ PCR containing $10 \times$ buffer (New England Biolabs, NEB), $5 \mathrm{mM}$ of dNTPs, $10 \mu \mathrm{M}$ of primers L-Thro and H12Sr5 (Yokoyama \& Goto 2002) and 1.5 units of Taq DNA polymerase (NEB). Thermal cycling conditions began with $3 \mathrm{~min}$ at $95^{\circ} \mathrm{C}, 1 \mathrm{~min}$ at $58^{\circ} \mathrm{C}, 1 \mathrm{~min}$ at $72^{\circ} \mathrm{C}$, with 5 cycles of $1 \mathrm{~min}$ at $94^{\circ} \mathrm{C}, 1 \mathrm{~min}$ at $58^{\circ} \mathrm{C}$ and $1 \mathrm{~min}$ at $72^{\circ} \mathrm{C}, 33$ cycles of $92^{\circ} \mathrm{C}$ for $45 \mathrm{~s}, 56^{\circ} \mathrm{C}$ for $30 \mathrm{~s}$ and $72^{\circ} \mathrm{C}$ for $1 \mathrm{~min}$, followed by a final extension step of $72^{\circ} \mathrm{C}$ for $10 \mathrm{~min}$. The PCR products were purified using the Qiagen QIAquick PCR purification kit and sequenced at the Nucleic Acids and Protein Service 
unit at the University of British Columbia on an ABI Prism 377 automated sequencer using L-Thr as the sequencing primer.

Sequences were edited using BioEdit v7.0.9.0 (Hall 1999) and aligned using ClustalX (Thompson et al. 1997). MrModeltest v2.3 (Posada \& Crandall 1998) was used to select a model for sequence evolution and genetic distance employing the Akaike Information Criterion (AIC; Posada \& Buckley 2004). PAUP* (Swofford 2002) was used for neighbour-joining tree analysis of pairwise genetic distances (average number of substitutions per site) incorporating 10000 bootstrap iterations of the sequence matrix. MrBayes v3.1.2 (Huelsenbeck \& Ronquist 2001) was also used for Bayesian estimates of phylogenetic relationships accompanied by posterior probabilities of nodes, with 1000000 generations run and summarized across 10000 sampled trees. As the neighbour-joining and Bayesian analyses produced very similar results, below we report only the results of the latter analysis.

\section{Microsatellite analysis}

We genotyped 350 fish at 8 Cottus gobio dinucleotide microsatellite loci (Nolte et al. 2005, Whiteley et al. 2009). These loci were amplified by PCR using fluorescently-labelled primers (see Tables S1 \& S2 in the Supplement at www.int-res.com/articles/suppl/ n020p181_supp.pdf) according to Qiagen's Multiplex PCR protocol using an annealing temperature of $60^{\circ} \mathrm{C}$ and 25 cycles. The PCR products were then diluted 1:20 before being assayed using a CEQ 8000 Genetic Analysis System and software (Beckman Coulter) with a CEQ DNA Size Standard Kit (400 bp) used as the internal size standard.

Micro-checker v2.2.3 (Van Oosterhout et al. 2004) was used to test for the presence of null alleles and to detect any technical problems with the microsatellite results. To obtain descriptive statistics, Tools For Population Genetic Analysis (TFPGA) (Miller 1997) provided observed $\left(H_{0}\right)$ and expected $\left(H_{\mathrm{e}}\right)$ heterozygosities, sample size $(\mathrm{N})$ and number of alleles. Genepop v3.4 (Raymond \& Rousset 1995) was used to detect any deviation from Hardy-Weinberg Equilibrium (HWE) and linkage disequilibrium, and also to test for differences in $F_{\mathrm{ST}}$ values and genotypic differentiation between all pairs of localities. STRUCTURE v2.3.3 (Pritchard et al. 2000) was used to estimate the number of distinct genetic clusters in the microsatellite data, both with and without prior locality information incorporated into the clustering (Hubisz et al. 2009).
The burn-in period was 50000 iterations, and the Markov Chain Monte-Carlo (MCMC) length was also 50000 (longer preliminary analyses produced identical results). There were 10 separate runs conducted for each population estimate $(K)$, and the average of each log likelihood value was used for each $K$ estimate. All 9 localities (Cheakamus River, Mamquam River, Squamish River, Cultus Lake [trawl and minnow trap fish combined], Frosst Creek [main inlet to Cultus Lake], Lake Washington, the 2 inlet streams tributary to Cultus Lake [Watt and Windfall Creeks combined], and Norrish Creek) were first tested, followed by an analysis including only the 3 localities within the Cultus Lake drainage (Cultus Lake, Frosst Creek, Windfall/Watt Creeks). Some samples were pooled (e.g. trawl and minnow trap samples from Cultus Lake; tributary samples from Windfall and Watt Creeks) because initial analyses indicated no significant differences between them, resulting in the subsequent microsatellite analysis of 8 'samples' (see 'Results'). The most likely model of population structure was determined as that value of $K$ with the highest mean log-likelihood. The ad hoc method of Evanno et al. (2005) was not employed owing to its poor performance at low levels of genetic differentiation (Waples \& Gaggiotti 2006) and the fact that the null model of $K=1$ cannot be evaluated with this method. As the use of locality information as priors did not influence the results, we report results for the non-locality prior models. Arlequin (Excoffier et al. 2005) was used to produce an analysis of molecular variance (AMOVA) that compared all sculpin samples grouped into regional locality assemblages: Squamish drainage (Squamish, Mamquam and Cheakamus Rivers), Cultus Lake (all Cultus Lake proper and tributary samples) and 'Other' (Norrish Creek and Lake Washington). The sequential Bonferroni correction was used to determine significance for tests that involved many simultaneous tests (Rice 1989).

\section{Behavioural assays of depth selection}

Two 'drop tanks' $1.8 \mathrm{~m}$ in height and $0.3 \mathrm{~m}$ square were used for the depth selection experiments. To minimize disturbance, the tanks were placed in an environmental chamber with white blinds on 3 sides (Houtman \& Dill 1994). The temperature in the environmental chamber was maintained at 14 to $16^{\circ} \mathrm{C}$. In the first experiment, each trial consisted of 1 fish being placed in each of the 2 drop tanks (the 'focal' fish). These fish were allowed to acclimate to the 
tanks for approximately 30 min while the camera was set up, and were then filmed with a web cam (Logitech QuickCam) attached to a laptop computer for $30 \mathrm{~min}$. In a second experiment, 1 sculpin from one of the 3 populations and 1 Cottus asper, a known predator, and likely competitor, of C. aleuticus (McPhail 2007), were placed in a tank together. There was no apparent difference in behaviour between 0-30 min (after camera set-up) and 30-90 min, so the filming took place in the first $30 \mathrm{~min}$ (Rogers et al. 2002, Rogers \& Bernatchez 2007). In all experiments and trials, the height from the bottom at which each focal fish was observed was recorded every minute, and then averaged for each fish across 30 measurements per trial (Rogers \& Bernatchez 2007). In addition, the total number of times that an individual fish left the bottom was recorded over the $30 \mathrm{~min}$ trials. Owing to the number of fish available for the experiments, the same animals were used in the $C$. asper-free and $C$. asper trials. The mean \pm SD size of sculpins used in these experiments was $55 \pm 4.2$ (Cultus Lake), $62 \pm$ 8.4 (Frosst Creek) and $86 \pm 11.8 \mathrm{~mm}$ (Little Campbell River) total length, and $62 \pm 8.3,74 \pm 5.5$ and $85 \pm$ $10.0 \mathrm{~mm}$ for tests without and with C. asper, respectively. The average size of C. asper used was $112 \pm$ $2.1 \mathrm{~mm}$.

Differences among populations in depth selected and in number of times moving off the bottom were assessed by analysis of variance, both in the absence and presence of Cottus asper, followed by TukeyKramer (Tukey HSD) post hoc pairwise tests (Whitlock \& Schluter 2009). All statistical analyses were completed in R v2.8.1 (R Development Core Team 2008).

\section{RESULTS}

\section{Mitochondrial DNA}

We resolved $41 \mathrm{mtDNA}$ sequence haplotypes (all sequences have been deposited in GenBank under accession nos. JX965047-JX965087); haplotype diversity was 0.986 and nucleotide diversity was 0.01105 . The best DNA substitution model selected by AIC was the GTR + I + G (general time reversible model [GTR; Tavaré 1986], with proportion of invariable sites [I] and gamma distribution [G]). The GTR model assumes that the probability of the data is independent of the placement of the root on the tree; that the relative rates of substitutions remain constant across the tree; and that the 4 nucleotides can be at different, but stationary, frequencies (Waddell
\& Steel 1997). The substitution rate varies among sites in a gamma distribution (the inferred shape of the gamma distribution of substitution rate variation among nucleotide positions was relatively rightskewed at $1.0277 ; \mathrm{Li}$ 1997). The proportion of invariable sites is the expected frequency of sites that do not evolve ( $\mathrm{I}=0.7046$; Waddell \& Steel 1997).

The Cultus pygmy sculpin samples were clearly very similar to known samples of Cottus aleuticus and both clustered together distinct from C. asper in our Bayesian phylogenetic reconstruction employing the GTR + I + G genetic distance (Fig. 2). The Cultus pygmy sculpin and coastrange sculpin samples from different areas along the Pacific coast, however, were intermingled with each other and, in particular, the Cultus pygmy sculpin did not form a monophyletic grouping distinct from C. aleuticus (Fig. 2). The average pairwise genetic distance amongst all samples and C. asper was 0.048 . By contrast, the average pairwise divergence between $C$. aleuticus sampled from outside the Cultus Lake drainage and Cultus pygmy sculpin sequences was 0.010 . The average pairwise divergence between Cultus pygmy sculpin and coastrange sculpin sampled from other areas of the Cultus Lake drainage was 0.005 .

\section{Microsatellite DNA}

Across the 8 microsatellite DNA loci we detected between 4 and 37 alleles, with individual populations having between 3 and 24 alleles at each locus (Table S3 in the Supplement). Cottus aleuticus from the Cultus Lake streams and the Cultus pygmy sculpin both had lower allelic richness $(p<0.05)$ when compared to the other $C$. aleuticus populations sampled (Table 2). No population failed to meet HWE expectations across all loci, and only 9 cases across 80 individual locus tests departed significantly from HWE (Table 2). Only 12 out of 280 tests showed evidence of departures from linkage equilibrium, but such departures tended to be idiosyncratic and not concentrated at particular loci or within particular populations. Micro-checker identified CottES19 to be a locus with possible null alleles that was associated with cases of heterozygotic deficiency/homozygote excess. The analyses were conducted with and without this locus, and no differences between results were observed; therefore, this locus was included in the analyses.

$F_{\mathrm{ST}}$ values across population comparisons ranged from 0.001 to 0.06 (Table 3), while the overall $F_{\mathrm{ST}}$ value was 0.03 . There was no significant difference 


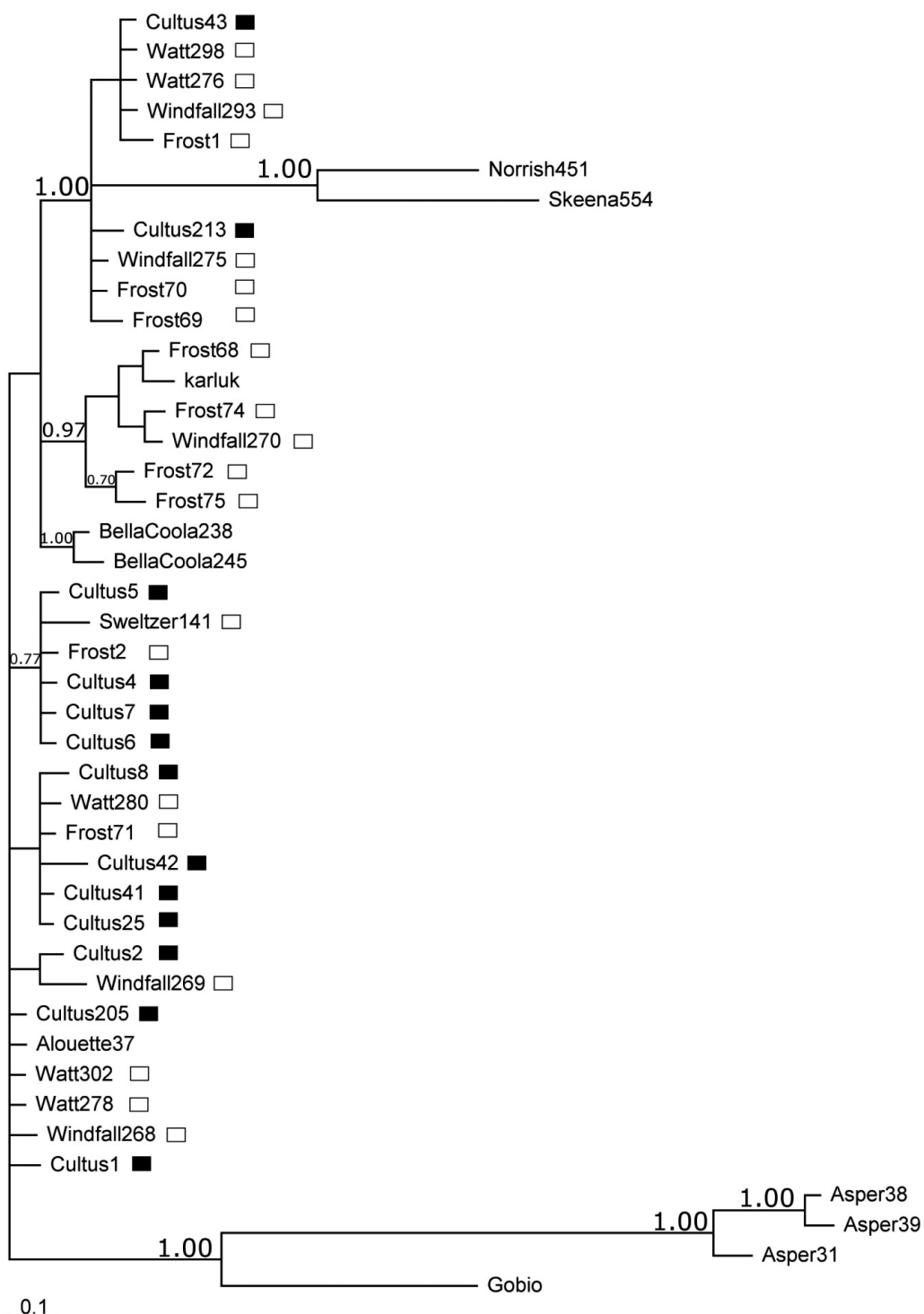

$\underline{0.1}$

Fig. 2. Cottus spp. Phylogenetic analysis of mtDNA D-loop across $775 \mathrm{nu}-$ cleotides under a GTR + I + G model (general time reversible model; G: gamma distribution; I: invariable sites) of sequence evolution. Asper: C. asper; Gobio: C. gobio. Filled squares indicate Cultus pygmy sculpin, open squares are $C$. aleuticus from Cultus Lake tributary streams, and all others are $C$. aleuticus from outside the Cultus Lake drainage. Values at nodes represent posterior probabilities for each node (only those $>0.70$ are shown), and the scale bar represents the GTR + I + G inferred genetic distances (expected average number of substitutions per site) sculpin sampled from the lake, the combined Windfall and Watt Creeks samples ('tributaries') and the Frosst Creek sample. The $F_{\mathrm{ST}}$ values between Cultus Lake pygmy sculpin and sculpin from Frosst Creek and the tributary samples were significantly greater than 0 , although these differences were much smaller than $F_{\mathrm{ST}}$ values between populations sampled from different watersheds (Table 3).

STRUCTURE analysis indicated that the most likely number of genetic groups across all 9 localities was 3 (Table 4). Group 1 predominated within the Cheakamus, Mamquam and Squamish Rivers and Norrish Creek; Group 2 within the Cultus Lake, Frosst Creek, and Watt and Windfall Creeks samples; and Group 3 predominated in the Lake Washington sample (Fig. 3a). The hierarchical analysis of genetic structure using AMOVA showed that about $2.0 \%(\mathrm{p}<0.001)$ of the total genetic variability could be attributed to differences among the Squamish River drainage (i.e. Squamish, Mamquam and Cheakmus Rivers), Cultus, and 'other' (Norrish Creek, Lake Washington) drainages and that the vast majority of remaining variation resided within populations.

STRUCTURE analysis conducted within the Cultus Lake drainage indicated that the most likely number of populations was 2 (Table 4, Fig. 3b). Differences were modest, but most individuals in the Frosst, Watt and Windfall Creeks assigned more strongly to one group (mean proportion group 1, mean $\mathrm{Q}_{1}=0.80,0.79$, and 0.77 , respectively) compared to the Cultus pygmy sculpin samples (mean $\mathrm{Q}_{1}=0.62$, Fig. 3b). in $F_{\mathrm{ST}}$ between coastrange sculpin sampled from Watt and Windfall Creeks ( $\mathrm{p}>0.05)$, so these 2 populations were combined for subsequent analyses. There was no significant difference between Cultus pygmy sculpin caught using trawl or minnow traps ( $p$ $>0.05$ ), so those 2 groups were also combined. Consequently, subsequent tests consisted of 3 groups of fish from the Cultus Lake drainage: Cultus pygmy

\section{Depth selection of sculpins}

When the fish were first introduced to the tank, their behaviour was variable, ranging from immediately heading to the bottom, to swimming around at different depths in the tank. No trends in initial behaviour were observed for any population (i.e. each individual fish seemed to have its own behavioural response). 
Table 2. Cottus spp. Descriptive statistics by locus and locality for microsatellite analysis. N: number of samples; $H_{\mathrm{e}}\left(H_{\mathrm{o}}\right)$ : expected (observed) heterozygosity; $A_{R}$ : allelic richness. Underlined values of $H_{0}$ indicate significant departures from HardyWeinberg expectations $(\mathrm{p}<0.008)$

\begin{tabular}{|c|c|c|c|c|c|c|c|c|c|}
\hline \multirow{2}{*}{ Locality } & & & & & \multirow{2}{*}{$\begin{array}{l}\text { Locus } \\
\text { LCE29 }\end{array}$} & \multirow[b]{2}{*}{ Cott635 } & \multirow[b]{2}{*}{ Cott582 } & \multirow[b]{2}{*}{ Cott255 } & \multirow[b]{2}{*}{ Mean } \\
\hline & Cott100 & CottES19 & Cott127 & Cott687 & & & & & \\
\hline \multicolumn{10}{|c|}{ Cheakamus River } \\
\hline $\mathrm{N}$ & 66 & 67 & 65 & 66 & 61 & 64 & 66 & 63 & 65 \\
\hline$H_{\mathrm{e}}$ & 0.908 & 0.800 & 0.745 & 0.777 & 0.878 & 0.856 & 0.784 & 0.838 & 0.823 \\
\hline$H_{\mathrm{o}}$ & 0.879 & $\underline{0.672}$ & 0.754 & 0.758 & 0.787 & $\underline{0.844}$ & 0.788 & 0.762 & 0.780 \\
\hline $\mathrm{A}_{\mathrm{R}}$ & 13.850 & 8.055 & 5.955 & 6.580 & 13.872 & 9.993 & 6.496 & 8.461 & 9.158 \\
\hline \multicolumn{10}{|c|}{ Mamquam River } \\
\hline $\mathrm{N}$ & 48 & 48 & 48 & 48 & 44 & 47 & 48 & 46 & 47 \\
\hline$H_{\mathrm{e}}$ & 0.919 & 0.823 & 0.720 & 0.734 & 0.893 & 0.873 & 0.821 & 0.812 & 0.824 \\
\hline$H_{\mathrm{o}}$ & 0.833 & 0.750 & 0.688 & 0.729 & 0.909 & 0.766 & 0.708 & 0.848 & 0.779 \\
\hline $\mathrm{A}_{\mathrm{R}}$ & 14.555 & 8.512 & 4.898 & 5.643 & 15.371 & 10.461 & 6.902 & 7.325 & 9.208 \\
\hline \multicolumn{10}{|c|}{ Squamish River } \\
\hline $\mathrm{N}$ & 31 & 31 & 30 & 30 & 32 & 32 & 31 & 31 & 31 \\
\hline$H_{\mathrm{e}}$ & 0.882 & 0.830 & 0.618 & 0.796 & 0.904 & 0.868 & 0.805 & 0.775 & 0.810 \\
\hline$H_{\mathrm{o}}$ & 0.774 & 0.613 & 0.733 & 0.733 & 0.906 & $\underline{0.750}$ & 0.742 & 0.839 & 0.761 \\
\hline $\mathrm{A}_{\mathrm{R}}$ & 12.657 & 8.584 & 4.739 & 6.523 & 16.098 & 10.061 & 5.911 & 6.059 & 8.829 \\
\hline \multicolumn{10}{|c|}{ Cultus trawl } \\
\hline $\mathrm{N}$ & 27 & 27 & 27 & 27 & 27 & 28 & 30 & 30 & 28 \\
\hline$H_{\mathrm{e}}$ & 0.865 & 0.826 & 0.521 & 0.620 & 0.821 & 0.830 & 0.757 & 0.748 & 0.749 \\
\hline$H_{\mathrm{o}}$ & 0.852 & $\underline{0.556}$ & 0.630 & 0.704 & 0.778 & $\underline{0.786}$ & $\underline{0.600}$ & 0.933 & 0.730 \\
\hline$A_{\mathrm{R}}$ & 9.985 & 8.501 & 4.254 & 4.579 & 11.162 & 9.567 & 6.302 & 4.000 & 7.294 \\
\hline \multicolumn{10}{|c|}{ Cultus traps } \\
\hline $\mathrm{N}$ & 27 & 28 & 26 & 26 & 24 & 26 & 24 & 24 & 26 \\
\hline$H_{\mathrm{e}}$ & 0.892 & 0.769 & 0.663 & 0.570 & 0.771 & 0.792 & 0.736 & 0.760 & 0.744 \\
\hline$H_{\mathrm{o}}$ & 0.963 & 0.607 & 0.769 & 0.539 & 0.667 & 0.846 & 0.708 & 0.792 & 0.736 \\
\hline $\mathrm{A}_{\mathrm{R}}$ & 12.168 & 7.037 & 4.617 & 3.617 & 9.219 & 10.420 & 6.315 & 5.627 & 7.378 \\
\hline \multicolumn{10}{|c|}{ Lake Washington } \\
\hline $\mathrm{N}$ & 26 & 25 & 21 & 25 & 27 & 27 & 28 & 27 & 26 \\
\hline$H_{\mathrm{e}}$ & 0.891 & 0.786 & 0.722 & 0.658 & 0.783 & 0.865 & 0.792 & 0.826 & 0.790 \\
\hline$H_{\mathrm{o}}$ & $\underline{0.808}$ & 0.800 & 0.524 & 0.760 & 0.852 & 0.852 & 0.679 & 0.889 & 0.770 \\
\hline $\mathrm{A}_{\mathrm{R}}$ & 13.835 & 5.679 & 7.206 & 5.040 & 9.512 & 11.059 & 7.630 & 8.315 & 8.535 \\
\hline \multicolumn{10}{|c|}{ Frosst Creek } \\
\hline $\mathrm{N}$ & 27 & 27 & 21 & 21 & 28 & 29 & 27 & 26 & 26 \\
\hline$H_{\mathrm{e}}$ & 0.844 & 0.758 & 0.571 & 0.514 & 0.722 & 0.669 & 0.748 & 0.771 & 0.700 \\
\hline$H_{\mathrm{o}}$ & 0.815 & 0.407 & 0.524 & 0.760 & 0.750 & 0.759 & 0.704 & 0.923 & 0.676 \\
\hline $\mathrm{A}_{\mathrm{R}}$ & 9.049 & 5.861 & 4.614 & 3.935 & 7.371 & 7.347 & 5.495 & 6.192 & 6.233 \\
\hline \multicolumn{10}{|c|}{ Windfall Creek } \\
\hline $\mathrm{N}$ & 23 & 24 & 23 & 23 & 22 & 23 & 23 & 23 & 23 \\
\hline$H_{\mathrm{e}}$ & 0.876 & 0.751 & 0.637 & 0.598 & 0.721 & 0.622 & 0.710 & 0.738 & 0.707 \\
\hline$H_{\mathrm{o}}$ & 0.957 & 0.583 & 0.609 & 0.478 & 0.864 & 0.652 & 0.609 & 0.609 & 0.670 \\
\hline $\mathrm{A}_{\mathrm{R}}$ & 10.883 & 4.708 & 4.478 & 4.475 & 7.223 & 7.187 & 7.090 & 4.936 & 6.373 \\
\hline \multicolumn{10}{|c|}{ Watt Creek } \\
\hline $\mathrm{N}$ & 29 & 28 & 29 & 29 & 28 & 28 & 30 & 29 & 29 \\
\hline$H_{\mathrm{e}}$ & 0.878 & 0.783 & 0.596 & 0.561 & 0.736 & 0.656 & 0.779 & 0.754 & 0.718 \\
\hline$H_{\mathrm{o}}$ & 0.931 & $\underline{0.607}$ & 0.655 & 0.690 & 0.750 & 0.714 & 0.667 & 0.724 & 0.717 \\
\hline $\mathrm{A}_{\mathrm{R}}$ & 10.839 & 7.515 & 4.169 & 2.975 & 7.829 & 8.660 & 6.914 & 6.103 & 6.876 \\
\hline \multicolumn{10}{|c|}{ Norrish Creek } \\
\hline $\mathrm{N}$ & 26 & 28 & 24 & 26 & 17 & 19 & 27 & 25 & 24 \\
\hline$H_{\mathrm{e}}$ & 0.896 & 0.847 & 0.578 & 0.654 & 0.863 & 0.850 & 0.833 & 0.810 & 0.791 \\
\hline$H_{\mathrm{o}}$ & 0.923 & $\underline{0.714}$ & 0.625 & 0.615 & 0.824 & 0.842 & 0.593 & 0.720 & 0.732 \\
\hline $\mathrm{A}_{\mathrm{R}}$ & 12.802 & 9.582 & 4.412 & 3.885 & 15.000 & 7.982 & 8.468 & 8.593 & 8.841 \\
\hline
\end{tabular}


Table 3. Cottus spp. Pairwise $F_{\mathrm{ST}}(\theta)$ values derived from allelic variation across 8 microsatellite DNA loci in various samples. Underlined values are not significantly different from 0 . The population in boldface represents the Cultus Lake pygmy sculpin. Samples in italics are found within the Cultus Lake drainage. Cheak: Cheakamus River; Mam: Mamquam River; Squam: Squamish River; Cultus: samples from fish caught by trawl and minnow trap in Cultus Lake; Frosst: Frosst Creek; Wash: Lake Washington; Tributaries: Watt and Windfall Creeks, Cultus Lake

\begin{tabular}{|llllllll|}
\hline Population & Cheak & Mam & Squam & Cultus & Frosst & Wash Tributaries \\
\hline Mamquam & $\underline{\underline{0.0037}}$ & & & & & & \\
Squamish & $\underline{\underline{0.0010}}$ & $\underline{0.0030}$ & & & & & \\
Cultus & 0.0384 & 0.0277 & 0.0445 & & & & \\
Frosst Creek & 0.0475 & 0.0438 & 0.0577 & 0.0111 & & & \\
Lake Washington & 0.0425 & 0.0314 & 0.0459 & 0.0405 & 0.0552 & & \\
Tributaries & 0.0511 & 0.0466 & 0.0536 & 0.0078 & $\underline{0.0069}$ & 0.0655 & \\
Norrish & 0.0113 & 0.0062 & 0.0106 & 0.0222 & 0.0346 & 0.0367 & 0.0414 \\
\hline
\end{tabular}

Table 4. Cottus spp. Results of STRUCTURE analysis based on variation across 8 microsatellite DNA loci across 8 samples (Cheakamus, Mamquam and Squamish Rivers; Cultus Lake pygmy sculpin and its 3 tributary streams: Frosst Creek and combined Watt and Windfall Creeks; Lake Washington; and Norrish Creek; log-likelihood-8) and across the 3 samples within the Cultus Lake drainage (Cultus Lake; Frosst Creek; and combined Watt and Windfall Creeks; log likelihood-3). The likelihood values for each hypothesized number of genetic groups $(K)$ are the average from 10 separate runs and represent the likelihood of each $K$ model of population structure given the microsatellite DNA allele frequency data. The underlined values represent the most likely number of populations

\begin{tabular}{|lcc|}
\hline$K$ & $\log$ likelihood-8 & log likelihood-3 \\
\hline 1 & -10597.9 & -3611.67 \\
2 & -10282.6 & -3585.12 \\
3 & -10167.1 & -3622.12 \\
4 & -10204.3 & -3641.41 \\
5 & -10291.8 & -3673.02 \\
6 & -10357.8 & -3655.73 \\
7 & -10393.0 & -3633.07 \\
8 & -10444.2 & -3631.91 \\
9 & -10424.5 & -3655.49 \\
10 & -10559.8 & -3662.75 \\
\hline
\end{tabular}

The depth distribution and the number of times fish were observed off the bottom were significantly different between the 3 populations both in the absence $(F=6.98, \mathrm{df}=2, \mathrm{p}=0.0016$, and $F=3.40$, $\mathrm{df}=2, \mathrm{p}=0.0038$, respectively) and the presence $(F=4.31, \mathrm{df}=2, \mathrm{p}=0.0176$ and $F=5.31, \mathrm{df}=2$, $\mathrm{p}=0.0074$, respectively) of Cottus asper. Overall, Cultus pygmy sculpin showed the highest position in the water column and the greatest frequency of moving off the bottom (average of $19.5 \mathrm{~cm}$ and 7.05 times per $30 \mathrm{~min}$, respectively) and sculpins from the Little Campbell River the lowest (average of 3.0 and 2.7 times per $30 \mathrm{~min}$, respectively), but this varied between treatments with and without $C$. asper (Table 5, Fig. 4). Contrary to expectations, Frosst Creek sculpins were highest in the water column on average in the absence of $C$. asper and moved off the bottom the most frequently (Cultus pygmy sculpin were intermediate for both measures), but only the differences between Frosst Creek and the Little Campbell River were significant (Table 5). The effect of addition of C. asper was opposite in the Cultus pygmy sculpin compared to sculpins from the other 2 populations: Cultus pygmy sculpin increased their height in the water column by an average of about $44 \%$ and were highest in the water column when with $C$. asper (maximum $\mathrm{p}=0.0409$, Table 5), whereas fish from the other 2 populations decreased their position in the water column by between 81 and $91 \%$ (Table 5 , Fig. 4). Fish from all populations decreased the number of times they left the bottom of the tanks between 19\% (Cultus pygmy sculpin) and 83\% (Little Campbell River sculpins, Table 5), when in the presence of C. asper, but Cultus pygmy sculpin were the most active in moving off the bottom (maximum $\mathrm{p}=0.0302$, Table 5).

\section{DISCUSSION}

\section{Mitochondrial and microsatellite DNA differentiation}

Our mtDNA results are the first data to confirm that the Cultus pygmy sculpin is indeed a form of Cottus aleuticus, an inference that had been made previously based on limited morphological comparisons (Ricker 1960, McPhail 2007). These data are further supported by microsatellite DNA analysis that included prickly sculpin from the Squamish River area that also showed a clear affinity between Cultus pygmy sculpin and C. aleuticus relative to samples of $C$. asper (E. B. Taylor et al. unpubl.). The mtDNA analysis also indicated that D-loop haplotypes of Cultus pygmy sculpin and $C$. aleuticus did not form reciprocally monophyletic clades and that samples of fish of the 2 ecotypes are very similar to one another genetically and show no phylogeographic distinctions; sequence divergence estimates between Cultus pygmy sculpin 


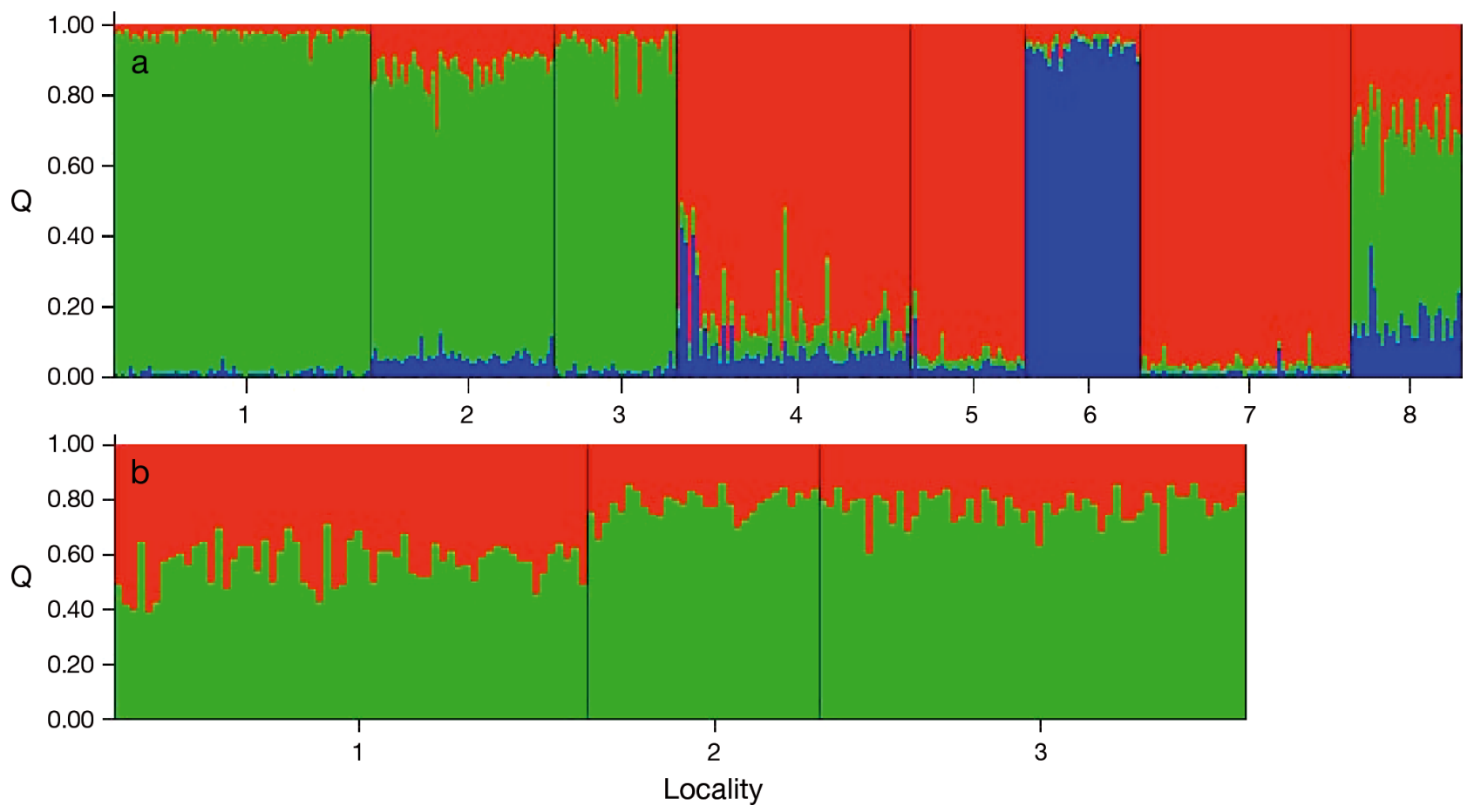

Fig. 3. Cottus spp. STRUCture results derived from variation at 8 microsatellite DNA loci across (a) 8 samples and $K=3$ genetic groups (green, blue, red), and (b) 3 samples within the Cultus Lake drainage and $K=2$ genetic groups (green, red). Each fish is represented by a thin vertical line composed of 1 to 3 colours, each of which represents the proportional contribution of each genetic group to a fish's genetic composition (Q) across 8 microsatellite loci. Localities in (a): $1=$ Cheakamus River; $2=$ Mamquam River; 3 = Squamish River; $4=$ Cultus pygmy sculpin (trawl and minnow trap fish combined); $5=$ Frosst Creek (main inlet to Cultus Lake); 6 = Lake Washington; $7=$ inlet streams tributary to Cultus Lake (Watt and Windfall Creeks); and 8 = Norrish Creek (tributary of mainstem Fraser River). Localities in (b): 1 = Cultus Lake pygmy sculpin (trawl and minnow trap fish combined); $2=$ Frosst Creek; $3=$ tributary streams (Watt and Windfall Creeks)

Table 5. Cottus spp. Average (SD) height in the water column occupied by individual fish and number of times fish moved off the bottom over $30 \mathrm{~min}$ in test tanks for Cultus pygmy sculpin (Cultus) and C. aleuticus from Frosst Creek and Little Campbell River (LCR). Expt 1 used a 'focal fish' in the absence of $C$. asper; Expt 2 used a 'focal fish' in the presence of C. asper. Superscripts indicate significance levels for pairwise comparisons between

Cultus vs. Frosst, Cultus vs. LCR, and Frosst vs. LCR, respectively

\begin{tabular}{|c|c|c|c|c|c|}
\hline \multirow{2}{*}{ Pop. } & \multirow{2}{*}{$\mathrm{N}$} & \multicolumn{2}{|c|}{$\longrightarrow$ Expt $1 \longleftarrow$} & \multicolumn{2}{|c|}{ - Expt 2} \\
\hline & & 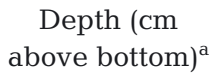 & $\begin{array}{l}\text { No. of times } \\
\text { off bottom }\end{array}$ & 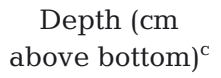 & $\begin{array}{l}\text { No. of times } \\
\text { off bottom }^{\mathrm{d}}\end{array}$ \\
\hline Cultus & 25 & $16.0(20.5)$ & $7.8(7.6)$ & $23.1(41.4)$ & $6.3(7.6)$ \\
\hline Frosst & 32 & $28.9(34.1)$ & $9.8(8.9)$ & $5.5(10.4)$ & $2.6(3.4)$ \\
\hline LCR & 27 & $5.4(7.4)$ & $4.6(5.8)$ & $0.5(1.3)$ & $0.8(2.1)$ \\
\hline
\end{tabular}

years, after the Wisconsinan ice sheets retreated (McPhail 1967, 2007). The recent emergence of the only known habitats presently occupied by these 2 pygmy populations of coastrange sculpin implies that these fish had a postglacial origin as well.

The diversity of microsatellite DNA variation within samples both of Cultus pygmy sculpin and in Cottus aleuticus from tributary streams within the drainage was high $\left(H_{\mathrm{e}} \sim 0.70\right)$, yet genetic differentiation between Cultus pygmy sculpin and Cultus tributary samples, although modest $\left(F_{\mathrm{ST}}\right.$ between 0.008 and 0.011), was statistically significant and suggests that they are genetically distinct

and parapatric coastrange sculpin were very low and consistent with differences between populations that have only recently diverged from one another (e.g. Bernatchez \& Wilson 1998, McPhail \& Taylor 1999). Cultus Lake (and nearby Lake Washington) only became accessible to fishes within the last 8000 to 10000 populations. These results are consistent with the few other studies that have been conducted on freshwater sculpins. For instance, Whiteley et al. (2009) found little evidence for genetic subdivision in some Alaskan populations separated by about $50 \mathrm{~km}\left(F_{\mathrm{ST}}<0.001\right)$, while fish in the 3 Squamish drainage rivers have an 


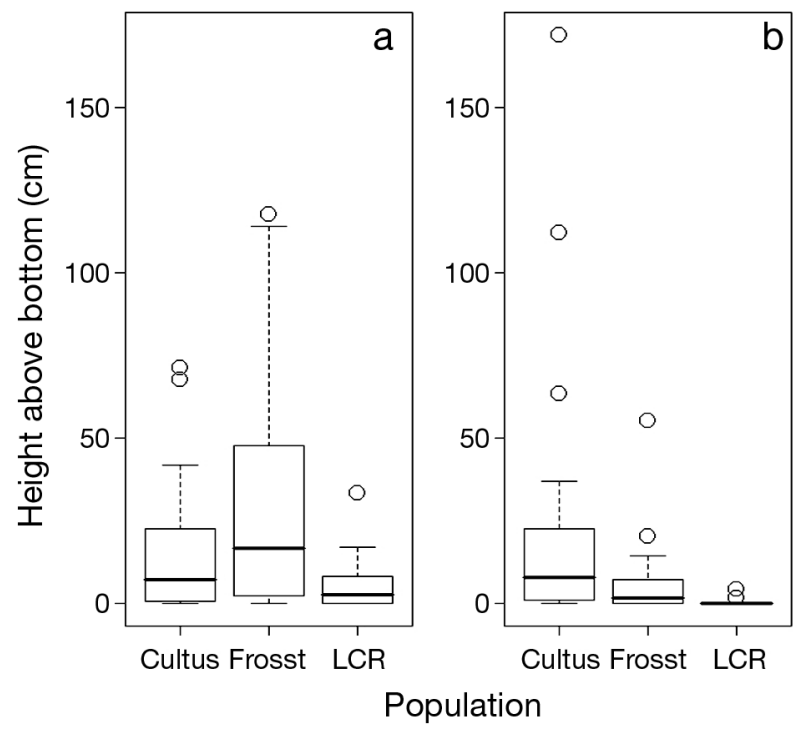

Fig. 4. Cottus spp. Distribution of the average depths occupied by sculpins in test tanks, with (a) no C. asper present and (b) C. asper present. Cultus: Cultus pygmy sculpin; Frosst: Frosst Creek coastrange sculpin; LCR: Little Campbell River coastrange sculpin. Thick horizontal line shows the median depth, with the top (bottom) of the box showing 75th (25th) percentiles (Crawley 2007). Dashed lines represent approximately $2 \mathrm{SD}$, circles represent outliers (Crawley 2007)

overall $F_{\mathrm{ST}}$ of 0.003 (E. B. Taylor et al. unpubl.). Consequently, compared with the low values observed in other systems (e.g. Alaska and Squamish River drainage), the differences that we have documented between Cultus pygmy sculpin and tributary fish from the Cultus Lake drainage are relatively large. Furthermore, we found that fish from Norrish Creek, a tributary to the north side of the lower Fraser River and located only about 27 river $\mathrm{km}$ from the outlet of Cultus Lake, were more similar genetically to fish from the Squamish River system (located some 150 river and sea $\mathrm{km}$ from Norrish Creek) than to fish from Cultus Lake. These relative relationships likely reflect a common evolutionary origin of $C$. aleuticuslike sculpins in southwestern BC and perhaps a greater potential for restrictions on ongoing gene flow between fish living in lake ecosystems (e.g. Cultus Lake) compared to those in larger rivers or small creeks directly connected to larger systems (e.g. Fraser River and Squamish River).

\section{Evolution and behaviour of Cultus pygmy sculpin}

Combined with the relatively recent time since postglacial colonization, large population sizes and high levels of dispersal, the amount of gene flow could be high enough to minimize the effects of genetic drift and explain the low interpopulation differentiation seen in sculpins across most of our study area (see also Whiteley et al. 2009). The most geographically distant population, Lake Washington, however, was highly distinct in the microsatellite analyses, which suggests that these fish had a separate origin from those in Cultus Lake. If so, this would suggest that the 2 known occurrences of pelagic Cottus aleuticus are a result of parallel evolution, i.e. similar traits have evolved in similar habitats independently. Both the Cultus pygmy sculpin and the Lake Washington sculpin are pelagic and live in the open waters of productive lakes, unusual for C. aleuticus (McPhail 2007) and sculpins in general, and have enlarged cephalic pores, shorter pelvic fins and a higher number of pectoral fin rays than typical (i.e. stream-resident) C. aleuticus (Larson \& Brown 1975, COSEWIC 2010). These morphological traits have been interpreted as adaptations to a pelagic life style, especially the enlarged cephalic pores and larger pectoral fins which may be advantageous in sensory detection in the pelagic zone and in maintaining position in the water column for a fish that lacks a swim bladder (a gas filled sac used in buoyancy regulation in most bony fishes). Interestingly, the 2 genera of pelagic sculpins from Lake Baikal are both characterized by greatly enlarged pectoral fins (e.g. Eshenroder et al. 1999). Other northwestern North American fishes have exhibited parallel evolution after glaciation, including sockeye/kokanee Oncorhynchus nerka (Taylor et al. 1996), threespine stickleback species pairs Gasterosteus aculeatus (Schluter \& McPhail 1993, Taylor \& McPhail 1999) and dwarf and normal lake whitefish Coregonus clupeaformis pairs across North America (Pigeon et al. 1997) and typically involving divergence along a pelagic/ limnetic-littoral/benthic axis (see reviews by Schluter 1996, Taylor 1999).

Similarly, the Cultus pygmy sculpin feeds primarily on zooplankton in the open water (Ricker 1960, McPhail 2007), and it is possible that interspecific competition with the larger, benthically oriented Cottus asper could have been an important factor favouring a pelagic life style observed in the Cultus pygmy sculpin. For instance, sculpin species tend to be spatially segregated; C. aleuticus is found in riffle habitat in streams and along the shorelines of lakes, while C. asper is found in stream pools and the deep benthic habitat of lakes, and it is only in the absence of $C$. asper that $C$. aleuticus are found in pools (McPhail 2007, Tabor et al. 2007). The Cultus pygmy sculpin, 
however, has only been found in the offshore benthic habitat of Cultus Lake, similar to the pelagic sculpin found in Lake Washington (Ikusemiju 1975, Larson \& Brown 1975). Both lakes are highly productive, in comparison to most other coastal lakes in BC, with Cultus Lake also having large numbers of Daphnia (an invertebrate food source) available year-round (Shortreed 2007). This concentrated food source, that also occurs below the thermocline within the colder water preferred by Cultus pygmy sculpin (Shortreed 2007), coupled with the large numbers of a potential competitor/predator on the bottom, could be an important factor in the adaptation and persistence of the Cultus pygmy sculpin. The lower productivity and greater depths of most coastal lakes in the $C$. aleuticus range could mean that a similar niche for a pelagic sculpin is not available in other lakes and Cultus Lake is the only lake where large numbers of pelagic $C$. aleuticus have been reported, although there is always the possibility that other as yet unsampled lakes contain pelagic sculpins (see Gow et al. 2008 for an example in sticklebacks Gasterosteus spp.; Woodruff 2010).

As many Holarctic fishes recolonized freshwater habitats after glaciations, vacant niches may have provided novel ecological opportunities and promoted divergence in aspects of resource exploitation among populations (Schluter 2000, Rogers et al. 2002). This process could explain how pelagic sculpin, such as the Cultus pygmy sculpin, developed specializations in water-column use for feeding and predator avoidance (Ikusemiju 1975, Rogers \& Bernatchez 2007), especially if the typical benthic niche was already being occupied by a potential competitor and predator such as congeneric Cottus asper. Our observation of changes in behaviour of Cultus pygmy sculpin and other $C$. aleuticus in the presence of $C$. asper is consistent with the idea that interactions between sympatric sculpins could influence their distributions. Notwithstanding this possibility, our behavioural data in the absence of $C$. asper were not consistent with our prediction that Cultus pygmy sculpin would be highest in the drop-tank water column. In addition, in all trials most fish were always within the lowermost $25 \mathrm{~cm}$ of the $1.8 \mathrm{~m}$ tall tank. The generally benthic or near-benthic behaviour of Cultus pygmy sculpin may reflect the inadequate representation of the Cultus Lake environment by our experimental apparatus. For instance, Cultus Lake has a mean depth of $31 \mathrm{~m}$, and fish are frequently caught in minnow traps and trawls 10 to $30 \mathrm{~m}$ above the bottom (Woodruff 2010). In addition, the pelagic behaviour of Cultus pygmy sculpin in nature may depend not only on the presence of predatory prickly sculpin in benthic areas, but also on the presence of Daphnia, a zooplankter which is heavily exploited by Cultus pygmy sculpin (Ricker 1960). The combination of the small depth range of our test tanks and lack of pelagic prey items may have compromised our ability to elicit pelagic-like behaviour in Cultus pygmy sculpin. This may be especially true for a Cultus pygmy sculpin whose ancestry clearly lies within the coastrange sculpin that, like all sculpins, lacks a swim bladder as an adult and is typically an almost exclusively benthically-oriented fish. By contrast, Rogers \& Bernatchez (2007) were able to demonstrate heritable differences between limnetic and benthic forms of lake whitefish in terms of their choice of water column depth in relatively shallow tanks, but whitefishes in general are much more characteristic of epibenthic to pelagic habitats in lakes and rivers compared to sculpins.

\section{Conservation status of the Cultus pygmy sculpin}

To qualify as a DU under COSEWIC guidelines, a population (or assemblage of populations) needs to satisfy 2 criteria: (1) it needs to be demonstrably discrete from other members of the same taxon in traits which may include, but are not limited to, differences in haplotype or allele frequencies, and (2) such discreteness must have some significance to the evolutionary legacy of the taxon (COSEWIC 2009). Previously described differences in life history and morphology of Cultus Lake pygmy sculpin satisfy the discreteness criterion (COSEWIC 2010). Our microsatellite data and, to a lesser extent, behavioural data add further support to the discreteness of Cultus Lake pygmy sculpin. One measure of evolutionary significance of difference in neutral loci is if they signal major phylogeographic, typically pre-glacial in origin, divisions (COSEWIC 2009). The relatively recent, postglacial divergence of the Cultus pygmy sculpin from the parapatric Cottus aleuticus, as suggested by the shallow divergences both in mtDNA and microsatellites, would appear not to satisfy the 'significance' conditions necessary for recognition as a distinct DU within C. aleuticus. The recognition of discrete groups as evolutionarily significant ones can, however, also be based on occupancy of habitats that are unique or unusual for the taxon being considered, particularly if they are associated or suspected to be associated with adaptations to such habitats (COSEWIC 2009). The pelagic habits of the Cultus pygmy sculpin and its aforementioned mor- 
phological traits that are plausibly interpreted as adaptations to such a rare lifestyle, support the recognition of these differences as evolutionarily significant. Further, our microsatellite evidence of the independent origin of pelagic sculpins in Cultus Lake and in Lake Washington suggest that such phenotypes are the result of parallel evolutionary divergence and another aspect of the significance of these phenotypes within the evolutionary legacy of $C$. aleuticus. Our results, in combination with earlier studies of the Cultus Lake pygmy sculpin, further support its status as a DU under Canada's SARA. The development of conservation categories like DUs is an example of conservation prioritization at the intraspecific level. Deep, historical phylogeographic divisions within species are widely accepted as important conservation units (e.g. Moritz \& Faith 1998). The case of the Cultus pygmy sculpin, however, illustrates the importance of considering a variety of traits, especially those like life history, morphology and behaviour, that may evolve more rapidly owing to natural selection, in assessing the significance of intraspecific variation that has arisen over relatively short (e.g. postglacial) timeframes (e.g. Allendorf et al. 1997, Taylor et al. 2011).

Acknowledgements. We thank J. Hume, S. MacLellan (Fisheries and Oceans Canada), G. Wilson and T. Woodruff for assistance with field collections, and T. Quinn, R. Dolighan, T. Bansak, A. Whiteley and R. Tabor for providing additional samples. M. Berbee, D. Irwin, J. Rosenfeld and anonymous reviewers provided helpful comments on our research. Grants awarded to E.B.T. from the World Wildlife Fund (Endangered Species Program), the Natural Sciences and Engineering Research Council of Canada (Discovery and Equipment Grant programs) and the British Columbia Ministry of Environment (Biodiversity Branch) are gratefully acknowledged.

\section{LITERATURE CITED}

Allendorf FW, Bayles D, Bottom DL, Currens KP and others (1997) Prioritizing Pacific salmon stocks for conservation. Conserv Biol 11:140-152

BCCDC (British Columbia Conservation Data Centre) (2012) BC species and ecosystems explorer. Available at www. env.gov.bc.ca/atrisk/toolintro.html

> Bernatchez L, Wilson CC (1998) Comparative phylogeography of Nearctic and Palearctic fishes. Mol Ecol 7:431-452

Bowen BW (1999) Preserving genes, ecosystems, or species? Healing the fractured foundations of conservation policy. Mol Ecol 8:S5-S10

COSEWIC (Committee on the Status of Endangered Wildlife in Canada) (2009) Guidelines for recognizing designatable units. Committee on the Status of Endangered Wildlife in Canada, Ottawa

COSEWIC (2010) Draft status report on Cultus pygmy sculpin (Cottus sp.). Committee on the Status of Endan- gered Wildlife in Canada, Ottawa. Available at www. cosewic.gc.ca

Crawley MJ (2007) The R book. John Wiley \& Sons, Chichester

> Eshenroder RL, Sideleva VG, Todd TN (1999) Functional convergence among pelagic sculpins of Lake Baikal and deepwater ciscoes of the Great Lakes. J Gt Lakes Res 25: 847-855

- Evanno G, Regnaut S, Goudet J (2005) Detecting the number of clusters of individuals using the software STRUCTURE: a simulation study. Mol Ecol 14:2611-2620

Excoffier L, Laval G, Schneider S (2005) Arlequin (version 3.0): an integrated software package for population genetics data analysis. Evol Bioinform Online 1:47-50

Gow J, Rogers SM, Jackson M, Schluter D (2008) Ecological predictions lead to the discovery of a benthic-limnetic sympatric species pair of threespine stickleback in Little Quarry Lake, British Columbia. Can J Zool 86:564-571

Hall TA (1999) BioEdit: a user-friendly biological sequence alignment editor and analysis program for Windows 95/98/NT. Nucleic Acids Symp Ser 41:95-98

Hilborn R, Quinn TP, Schindler DE, Rogers DE (2003) Biocomplexity and fisheries sustainability. Proc Nat Acad Sci USA 100:6564-6568

Houtman R, Dill LM (1994) The influence of substrate colour on the alarm response of tidepool sculpins (Oligocottus maculosus; Pisces, Cottidae). Ethology 96:147-154

> Hubisz M, Falush D, Stephens M, Pritchard J (2009) Inferring weak population structure with the assistance of sample group information. Mol Ecol Resour 9:1322-1332

Huelsenbeck JP, Ronquist F (2001) MrBayes: Bayesian inference of phylogeny. Bioinformatics 17:754-755

Ikusemiju K (1975) Aspects of the ecology and life history of the sculpin, Cottus aleuticus (Gilbert), in Lake Washington. J Fish Biol 7:235-245

Kontula T, Kirilchik SV, Vainola R (2003) Endemic diversification of the monophyletic cottoid fish species flock in Lake Baikal explored with mtDNA sequencing. Mol Phylogenet Evol 27:143-155

> Larson KW, Brown GW Jr (1975) Systematic status of a midwater population of freshwater sculpin (Cottus) from Lake Washington, Seattle, Washington. J Fish Res Board Can 32:21-28

Li WH (1997) Molecular evolution. Sinauer Associates, Sunderland, MA

McPhail JD (1967) The distribution of freshwater fishes in western Washington. Northwest Sci 41:1-11

> McPhail JD (1984) Ecology and evolution of sympatric sticklebacks (Gasterosteus): morphological and genetic evidence for a species pair in Enos Lake, British Columbia Can J Zool 62:1402-1408

McPhail JD (2007) The freshwater fishes of British Columbia. University of Alberta Press, Edmonton, AB

McPhail JD, Taylor EB (1999) Morphological and genetic variation in northwestern longnose suckers, Catostomus catostomus: the Salish sucker problem. Copeia 1999: 884-893

Miller MP (1997) Tools for population genetic analysis. Version 1.3: a Windows program for the analysis of allozyme and molecular population genetic data. Department of Biological Sciences, Northern Arizona University, Flagstaff, AZ

> Moritz C, Faith DP (1998) Comparative phylogeography and the identification of genetically divergent areas for conservation. Mol Ecol 7:419-429 
National Recovery Team for Cultus Pygmy Sculpin (2007) Recovery strategy for Cultus pygmy sculpin (Cottus sp.) in Canada. Species at Risk Act Recovery Strategy Series. Fisheries and Oceans Canada, Ottawa

Nolte AW, Stemshorn KC, Tautz D (2005) Direct cloning of microsatellite loci from Cottus gobio through a simplified enrichment procedure. Mol Ecol Notes 5:628-636

$>$ Pigeon D, Chouinard A, Bernatchez L (1997) Multiple modes of speciation involved in the parallel evolution of sympatric morphotypes of lake whitefish (Coregonus cleupeaformis, Salmonidae). Evolution 51:196-205

Posada D, Buckley TR (2004) Model selection and model averaging in phylogenetics: advantages of Akaike Information Criterion and Bayesian approaches over likelihood ratio tests. Syst Biol 53:793-808

Posada D, Crandall KA (1998) Modeltest: testing the model of DNA substitution. Bioinformatics 14:817-818

Pritchard JK, Stephens M, Donnelly P (2000) Inference of population structure using multilocus genotype data. Genetics 155:945-959

R Development Core Team (2008) R: a language and environment for statistical computing. R Foundation for Statistical Computing, Vienna. Available at www.Rproject.org

Raymond M, Rousset F (1995) Genepop (version 3.2): population genetics software for exact tests and ecumenicism. J Hered 86:248-249

$>$ Rice WR (1989) Analyzing tables of statistical tests. Evolution 43:223-225

Ricker WE (1960) A population of dwarf coastrange sculpins (Cottus aleuticus). J Fish Res Board Can 17:929-932

Rogers SM, Bernatchez L (2007) The genetic architecture of ecological speciation and the association with signatures of selection in natural lake whitefish (Coregonus sp. Salmonidae) species pairs. Mol Biol Evol 24:1423-1438

Rogers SM, Gagnon V, Bernatchez L (2002) Genetically based phenotype-environment association for swimming behaviour in lake whitefish ecotypes (Coregonus clupeaformis Mitchell). Evolution 56:2322-2329

Schluter D (1996) Ecological speciation in postglacial fishes. Philos Trans R Soc Lond B Biol Sci 351:807-814

Schluter D (2000) Ecological character displacement in adaptive radiation. Am Nat 156 (Supplement):S4-S16

Schluter D, McPhail JD (1993) Character displacement and replicate adaptive radiation. Trends Ecol Evol 8:197-200

Sheldon TA, Mandrak NE, Lovejoy NR (2008) Biogeography of the deepwater sculpin (Myoxocephalus thompsonii), a Nearctic glacial relict. Can J Zool 86:108-115

Shortreed KS (2007) Limnology of Cultus Lake, British Columbia. Can Tech Rep Fish Aquat Sci 2753:1-85

Swofford DL (2002) PAUP*: phylogenetic analysis using parsimony. Ver. 4.0b10. Sinauer Associates, Sunderland, MA

Editorial responsibility: Cornelius Hammer,

Rostock, Germany
Tabor RA, Fresh KL, Paige DK, Warner EJ, Peters RJ (2007) Distribution and habitat use of cottids in the Lake Washington basin. Am Fish Soc Symp 53:135-150

Tavaré S (1986) Some probabilistic and statistical problems in the analysis of DNA sequences. Lect Math Life Sci 17: $57-86$

> Taylor EB (1999) Species pairs of north temperate freshwater fishes: evolution, taxonomy, and conservation. Rev Fish Biol Fish 9:299-334

> Taylor EB, McPhail JD (1999) Evolutionary history of an adaptive radiation in species pairs of threespine sticklebacks Gasterosteus: insights from mitochondrial DNA. Biol J Linn Soc 66:271-291

Taylor EB, Foote CJ, Wood CC (1996) Molecular genetic evidence for parallel life history evolution within a Pacific salmon (sockeye salmon and kokanee, Oncorhynchus nerka). Evolution 50:401-416

Taylor EB, Tamkee P, Keeley E, Parkinson E (2011) Conservation prioritization in widespread species: the use of genetic and morphological data to assess population distinctiveness in rainbow trout (Oncorhynchus mykiss) from British Columbia, Canada. Evol Appl 4:100-115

> Thompson JD, Gibson TJ, Plewniak F, Jeanmougin F, Higgins DG (1997) The ClustalX-Windows interface: flexible strategies for multiple sequence alignment aided by quality analysis tools. Nucleic Acids Res 25:4876-4882

> Van Oosterhout C, Hutchinson WF, Wills DPM, Shipley P (2004) Micro-checker: software for identifying and correcting genotyping errors in microsatellite data. Mol Ecol Notes 4:535-538

- Waddell PJ, Steel MA (1997) General time reversible distances with unequal rates across sites: mixing and inverse Gaussian distributions with invariant sites. Mol Phylogenet Evol 8:398-414

- Waples RS, Gaggiotti O (2006) What is a population? An empirical evaluation of some genetic methods for identifying the number of gene pools and their degree of connectivity. Mol Ecol 15:1419-1439

Whiteley AR, Gende SM, Gharrett AJ, Tallmon DA (2009) Background matching and color-change plasticity in colonizing freshwater sculpin populations following rapid deglaciation. Evolution 63:1519-1529

Whitlock MC, Schluter D (2009) The analysis of biological data. Roberts and Company Publishers, Greenwood Village, $\mathrm{CO}$

Woodruff PE (2010) A genetic and behavioural analysis of the distinctiveness of the Cultus pygmy sculpin (Cottus aleuticus) and implications for its conservation. $\mathrm{MSc}$ thesis, University of British Columbia, Vancouver

- Yokoyama R, Goto A (2002) Evolutionary history of freshwater sculpins, genus Cottus (Teleostei; Cottidae) and related taxa, as inferred from mitochondrial DNA phylogeny. Mol Phylogenet Evol 36:654-668

Submitted: September 24, 2012; Accepted: January 4, 2013 Proofs received from author(s): April 17, 2013 